\title{
Pre-service Science Teachers' Understanding of Chemistry: A Factorial Design Study
}

\author{
Ayfer Mutlu 1*, Burçin Acar-Şeşen ${ }^{2}$ \\ ${ }^{1}$ Kirklareli University, Kirklareli, TURKEY \\ 2 Istanbul University, Istanbul, TURKEY
}

Received 21 September 2017 - Revised 10 April 2018 • Accepted 22 April 2018

\begin{abstract}
This study compared the effect of the instructional treatments (guided inquiry-based and traditional recipe-like approach) and the learning environments (authentic and virtual learning environments) on pre-service science teachers' understanding of chemistry concepts. For this purpose, Authentic Inquiry-based Laboratory, Virtual Inquiry-based Laboratory, Authentic Recipe-like Laboratory and Virtual Recipe-like Laboratory were designed. Eight laboratory activities related to thermochemistry, chemical kinetics, chemical equilibrium, acids and bases and electrochemistry were developed. Sixty-eight pre-service science teachers were randomly stratified into four equal groups: Authentic Inquiry-based Laboratory, Virtual Inquiry-based Laboratory, Virtual Recipe-like Laboratory and Authentic Recipe-like Laboratory. A two-tier General Chemistry Concept Test developed by researchers was used for the data collection tool before and after the treatment and data were analysed using nonparametric statistical methods. According to the results there was a significant difference between post test scores of groups and this difference was between Authentic Inquiry-based Laboratory and Authentic Recipe-like Laboratory, Virtual Inquiry-based Laboratory and Authentic Recipe-like Laboratory. Mean scores of groups were arranged from the highest to the least as Authentic Inquiry-based Laboratory, Virtual Inquiry-based Laboratory, Virtual Recipe-like Laboratory and Authentic Recipe-like Laboratory. Each item of the test was also analysed and changing of alternative conceptions was assessed. Decreasing of frequencies of alternative conceptions were generally arranged same as mean scores except for chemical kinetics.
\end{abstract}

Keywords: guided inquiry-based learning; understanding of chemistry concepts, virtual laboratory

\section{INTRODUCTION}

For the last decades, science educators have emphasized the necessity of students to acquire knowledge by themselves via investigation, thinking scientifically like a scientist, not only to prove scientific facts but also to inquire these facts. Doing experiment is one of the most important ways for questioning of scientific facts like a scientist; therefore, laboratory instructions for training students have came into prominence.

Laboratory instructions take an important place in science education because science subjects cannot be learned meaningfully without laboratory instructions (Hofstein \& Lunetta, 1982, 2004; Hofstein \& Mamlok-Naaman, 2007; Tobin, 1990). In addition, the laboratory instructions are effective in the understanding of science concepts, improving scientific process skills and problem-solving skills (Hofstein \& Mamlok-Naaman, 2007; Lunetta, 1998). Moreover, the laboratory instructions enable the students to use more than one of their sense organs to investigate

This study is a part of Ayfer Mutlu's PhD Dissertation under the supervision of Burçin Acar Şeşen This study was supported by Istanbul University Scientific Research Project Department (Project Number: 16241, 33682)

(C) 2018 by the authors; licensee Modestum Ltd., UK. This article is an open access article distributed under the terms and conditions of the Creative Commons Attribution License (http://creativecommons.org/licenses/by/4.0/). $\square$ ayferkaradas@gmail.com (*Correspondence) $\square$ bsesen@istanbul.edu.tr 


\section{Contribution of this paper to the literature}

- There is limited research that evaluates understanding by using a two-tier diagnostic test and there is no study uses a $2 \times 2$ factorial design. This study was aimed to investigate the effect of the instructional treatment (guided inquiry-based and traditional recipe-like approach) and the learning environments (authentic and virtual learning environments) on the pre-service science teachers' understanding using $2 x$ 2 factorial design.

- According to the results, the guided inquiry-based approach was more effective than the traditional recipelike approach both authentic and virtual laboratory environments on the pre-service science teachers' understanding and remedying of alternative conceptions.

- An authentic laboratory environment was more beneficial than a virtual environment when it was supported by guided inquiry-based learning; virtual environment was more effective than authentic laboratory environment when it was based on the traditional recipe-like approach.

events and materials directly, to make them active in the learning process, to develop their research and investigation skills, to apply their learning to daily life and to observe repeatedly (Karamustafaoglu \& Yaman, 2010).

\section{Authentic Laboratory vs Virtual Laboratory}

Although the laboratory has many benefits, there are some limitations to using it, such as sharing a laboratory with different courses, negative attitudes of teachers about laboratory management, crowded classrooms, using dangerous and expensive chemicals/materials/equipment, long and dangerous experiments (Altun et al., 2009). In recent years, virtual laboratories have become popular to overcome these limitations (Altun, Feyzioglu \& Demirag, 2011; Tuysuz, 2010). Virtual laboratories are defined as environments that give a chance to students to do an experiment for turning their theoretical knowledge into practice by performing the simulation of a real laboratory (Woodfield, 2005). In the virtual laboratory, learning can be out of a classroom and instructions become more dynamic when a computer is available (Yang \& Heh, 2007). They have provided a learning environment that is interactive, safe and independent of time and classroom (Altun et al., 2011; Dalgarno, 2015; Tuysuz, 2010). Students can stop, resume and repeat the experiment (Gershenson, Gonzalez, \& Negrete, 2000), therefore they have an opportunity to conduct the experiment according to their individual learning (Stieff \& Wilensky, 2003). In addition, virtual laboratories enable simulation of both macroscopic and microscopic properties of chemical reactions, concurrently (Tuysuz, 2010). Some chemical reactions may occur very fast, very slow or in a very complex way and virtual laboratories make it possible to observe these reactions (Singer, Hilton, \& Schweingruber, 2006). Moreover, students can conduct a dangerous, long and expensive experiment in these laboratories in a safe learning environment (Dalgarno, Bishop, \& Bedgood, 2003; Gershenson et al., 2000; Kamlaskar, 2007). Students can become familiar with the experimental process (Georgiou, Dimitropoulos, \& Manitsaris, 2007), and both communication and interaction can be promoted by using this virtual environment (Lily et al., 2008; Yang \& Heh, 2007). On the other hand, students in the virtual laboratory virtually complete experiments, as if they were in an authentic laboratory environment, they could not use and improve their psychomotor skills in the virtual environment (Carnevale, 2003; Diker, 2011). They also do not touch laboratory materials, have interaction with laboratory materials and chemicals and they pay minimal attention to safety rules (Bucos, Dragulescu, \& Ternauciuc, 2008).

In recent years, the demand for virtual laboratories has increased because they have overcome real laboratories limitations and the research that investigates laboratory instructions has focused on the effects of virtual laboratory environments (Altun et al., 2011; Bakar \& Zaman, 2007; Bozkurt, 2008; Bucos et al., 2008; Carnevale, 2003; Diker, 2011; Hawkins \& Phelps, 2013; Jezierska, Podraza, Domek, \& Szwed, 2016; Kennepohl, 2001; Mercer-Chalmers, Goodfellow, \& Price, 2004; Tatli, 2011; Trindade, Fiolhais, \& Almedia, 2002; Tuysuz, 2010; Yang \& Heh, 2007). In a highlight of these studies, it was emphasized following situations about virtual laboratories: Traditional recipe-like laboratories have some limitations such as safety problems, long and dangerous experiments, expensive chemicals and equipment, the necessity of a place and obligation of conducting an experiment fixed time. Because of these limitations, laboratory instructions are not accomplished using their full potential efficiently. Considering these situations, in the virtual laboratory studies, more dynamic, independent of place and time, interactive learning environments were presented to participants. Participants conducted an experiment actively, they could repeat the whole experiment or any step. Therefore, they had the opportunity to conduct them at their individual learning pace and convenience. They could also observe microscopic levels of the experiment. As a result of these, achievement and performance were promoted and students felt relax, less tired and safer. They also became familiar with the experimental process, chemicals and equipment students could focus on the experiment rather than the use of chemicals/equipment, the danger of experiment or cost. These advantages enhanced students' 
inquiry skills, high-level cognitive skills, motivation and interest. However, these virtual laboratories could not provide some opportunities of authentic laboratories as mentioned previous paragraph.

\section{Inquiry-based Learning Approach and Laboratory Applications}

One of the limitations of laboratory instructions is having to carry out the laboratory activities in a particular sequence. However, science educators have discussed the inadequacies of traditional cook-book laboratory instructions for many years. For example, the students who conducted traditional cook-book laboratory activities focus on carrying out an experiment by following the directions. In addition, these directions have more details and this situation leads to misunderstanding the experiment's aim (Johnstone \& Wham, 1982). In addition, the students prove scientific facts without discussing them in traditional cook-book laboratory activities (Roth, 1994). Therefore, they do not understand the aim of experiment and related learning issues (Hofstein \& Lunetta, 2004). Moreover, the students in both science classes and science laboratories think that knowledge in a book and other sources is enough and they do not inquire into this knowledge's source. However, inquiring is an important component of science program at each level and in each area (Crowther, 1999). For this reason, inquiry-based learning takes an important place in science education.

Inquiry-based learning is expressed as activities that are improved by students' knowledge and in which they learn how scientists work (NRC, 2000). This approach which ensued in the light of constructivist approach attaches great importance to research process rather than problem solving (Lim, 2001). In addition, an inquiry-based learning approach provides an opportunity to improve students' scientific content knowledge, their perceptions about the nature of science and their inquiring skills for using it (NRC, 2000). Moreover, students have another opportunity to get an understanding of fundamental concepts and theories, comprehending of facts and events, improving questioning and answering (Chiappetta \& Adams, 2004). Briefly, science education turns from watching and listening activities to doing activities (Hinrichsen \& Jarrett, 1999).

Inquiry-based learning was first classified into three levels by Schwab according to activeness of teacher and students (Schwab, 1962). Then, these levels were revised and new levels were added to them. These levels are confirmation inquiry, structured inquiry, guided-inquiry, double inquiry and open inquiry. While students are the most active in open inquiry, the teacher is the most active in confirmation inquiry. In guided inquiry, a problem is given to students by the teacher and they investigate methods and solutions under the guidance of a teacher (Colburn, 2000).

Inquiry-based learning is more effective in laboratory instructions because laboratories are environments in which you can teach to invent and ways of achieving knowledge rather than to prove the knowledge. In the inquirybased laboratory, students do not follow directions step by step and they have an opportunity to work in a small cooperative group, to increase their responsibility (Coppola \& Lawton, 1995), to be familiar with planning and conducting research and to conduct new research easily by this way (Wimmers, 2001). Basically, an inquiry-based laboratory experiment has two phases: Pre-inquiry and inquiry (Hofstein, Shore, \& Kipnis, 2004). In the pre-inquiry phase, students carry out a short experiment to focus on the inquiry process. In the inquiry phase, they formulate hypothesis/hypotheses by asking relevant questions and they choose one of them to investigate. Then, they plan and conduct an experiment to prove their hypothesis/hypotheses. In this process, they note their observations and results obtained from the experiment. Finally, they discuss whether the hypothesis is accepted or not among their group members and they present their results in a scientific way (Hofstein et al., 2004).

Inquiry-based learning has many benefits in the learning process, but inquiry-based activities are limited (Cheung, 2008). Furthermore, inquiry-based laboratory research on students' understanding at the undergraduate level and especially at the teacher training level is limited (e.g. Akben, 2015; Almuntasheri, Gillies, \& Wright, 2016; Buckner \& Kim, 2014; Franklin et al., 2015; Hemraj-Benny \& Beckford, 2014; Hsiao et al., 2017; Kaya \& Yilmaz, 2016; Ozkan \& Bumen, 2014; Ramnarain, 2014; Yetişir, 2016).

In this study, the pre-service science teachers' understanding of chemistry concepts, namely, chemical kinetics, chemical equilibrium, thermochemistry, acids-bases and electrochemistry was investigated. For this purpose, four different learning environments were designed. According to the literature review, there is limited research inquiry-based laboratory, virtual chemistry laboratory, inquiry-based virtual chemistry laboratory studies for students' understanding related to the aforementioned concepts at the undergraduate level and especially at the teacher-training level are limited. In addition to these, there is much research that assessed the effect of only instructional treatment of mentor-only learning environment on different variables. Although there is some research focused on only one chemistry topic, this research focused on five chemistry topics and it was conducted during one semester. Our research differentiated from other research with these aspects and it will make a major contribution to the literature in this respect.

Understanding of teachers has a great role in students' meaningful understanding. Chemistry concepts also have great place in a science subject. If a teacher has alternative conceptions, they will teach them to their students. 
For this reason, training of pre-service teachers and remedying their alternative conceptions have a major importance. For this purpose, different and effective learning environments should be prepared and evaluated especially at the teacher-training level.

\section{Purpose of the Research}

This study to investigate the effect of instructional treatments (guided inquiry-based and traditional recipe-like approach) and the learning environments (authentic and virtual learning environments on the pre-service science teachers' understanding. The following research question was investigated in this study:

Do the instructional treatments and the learning environments affect the pre-service science teachers' understanding of chemistry concepts?

\section{METHOD}

\section{Participants}

This study was conducted with the participation of 68 pre-service science teachers (19-22 years) in an education faculty in Istanbul, Turkey. All the participants had learned basic chemistry concepts in the General Chemistry course in the first semester. They had also learned laboratory rules, laboratory safety, and laboratory methods.

The pre-service science teachers were stratified according to the pre-test scores obtained from the General Chemistry Concept Test, gender and age, and then they were randomly assigned to four groups (Table 1): Authentic Inquiry-based Laboratory (AIL), Virtual Inquiry-based Laboratory (VIL), Virtual Recipe-like Laboratory (VRL) and Authentic Recipe-like Laboratory (ARL).

Table 1. The distribution of pre-service science teachers

\begin{tabular}{|c|c|c|c|c|c|}
\hline & & AIL & VIL & VRL & ARL \\
\hline \multirow{3}{*}{$\begin{array}{l}\text { Pre-Test Results of General Chemistry } \\
\text { Concept Test }\end{array}$} & Low (4-8) & 6 & 5 & 6 & 6 \\
\hline & Medium (9-12) & 5 & 6 & 6 & 6 \\
\hline & High (13-16) & 6 & 6 & 5 & 5 \\
\hline \multirow{2}{*}{ Gender } & Female & 14 & 14 & 15 & 14 \\
\hline & Male & 3 & 3 & 2 & 3 \\
\hline \multirow{2}{*}{ Age } & 19 & 14 & 13 & 15 & 14 \\
\hline & $19+$ & 3 & 4 & 2 & 3 \\
\hline
\end{tabular}

\section{Ethical Procedures}

This study was conducted with the participation of 68 pre-service science teachers (19-22 years). Before the research, the participants were informed about the study. For this purpose, a guide form was prepared by the researcher containing headings:

- Heading of the research

- Aim of the research

- Importance of the research

- Basic steps of the research

- Ethical explanations

In the ethical explanation section, it was explained that there was no obligation or sanction for participating in the research. After reading the form, the participants declared that they volunteered for the study by signing this form.

This study was conducted using chemical and laboratory equipment. For this reason, brief information was given to participants about laboratory safety rules. The instructor also took precautions before each activity for protecting the participants from harm.

The last point of ethical procedure was the gatekeeper of the research. Because one of the researchers was the instructor of the lesson at the same time, activities were conducted by the instructor. In addition, the other researcher made observations during the instructions. 


\section{Instruments}

General Chemistry Concept Test. To determine the pre-service science teachers' understanding before and after the instructions, a two-tier diagnostic General Chemistry Concept Test (GCCT) developed by researchers based on Treagust's method (1988), in which 44 items related to thermochemistry, chemical kinetics, chemical equilibrium, acids-bases and electrochemistry, was used First, content boundaries and the learning objectives were determined. Alternative conceptions were derived both from literature review and the pre-service science teachers' semi-structured interviews. Then, a multiple-choice test with an open ended part, in which the pre-service science teachers were required to explain their reason for their answers to the first part, was constructed and applied to the 68 pre-service science teachers. Their responses to the open-ended part of each item were analysed, these results and alternative conceptions derived from the literature were used for constructing the distracters. Hence, the twotier test was constructed in a way that the first tier included a conventional multiple-choice step and the second tier included possible reasons of the given answer for the first tier. For the content validity, the test was reviewed by five chemistry educators and it was applied to 151 pre-service science teachers. According to the item analysis results, two items were removed from the test because of having negative discrimination indices. The difficulty levels were 0.3 and 0.77 with an average of 0.50 ; discrimination levels were identified between 0.2 and 0.64 and average of them was calculated as 0.39 . For reliability analysis, Cronbach's alpha reliability coefficient was calculated and reported because coefficient alpha is equivalent to the Kuder-Richardson 20 coefficient for dichotomous data (Green \& Salkind, 2005). The final version of the two-tier diagnostic test consisted of 44 items and the language of the test was Turkish. The Cronbach a reliability coefficient was found to be 0.84 (Table 2) and this value was high and acceptable when compared with the literature values (e.g. Chandrasegaran, Treagust \& Mocerino, 2007; Tsui \& Treagust, 2010). Answer all the questions on the test took nearly 90 minutes.

Table 2. Test topics and items

\begin{tabular}{ll}
\hline Topic & Items \\
\hline Thermochemistry & Q6, Q15, Q24, Q35, Q41, Q44 \\
\hline Chemical Kinetics & Q1, Q4, Q7, Q8, Q10, Q11, Q12, Q14, Q16, Q18, Q38 \\
\hline Chemical Equilibrium & Q27, Q30, Q32, Q34, Q36 \\
\hline Acids and Bases & Q2, Q5, Q9, Q13, Q17, Q19, Q20, Q21, Q23, Q25, Q28, Q29, Q31, Q37, Q42, Q43 \\
\hline Electrochemistry & Q3, Q22, Q26, Q33, Q39, Q40 \\
\hline
\end{tabular}

\section{Research Design}

In the present study, the effectiveness of the guided-inquiry approach and traditional recipe-like approach in different learning environments on the pre-service science teachers' understanding was compared. Therefore, participants were stratified into four groups and $2 \times 2$ factorial design, in which the instructional treatment and learning environment were adopted as independent variables, was used (Table 3). The pre-test and post-test with control group design was modified in this research design and it provided an assessment for both the separate effects of each independent variable and their joint effects (Fraenkel, Wallen, \& Hyun, 2012). This research design allows researchers to assess the interaction of a variable with one or more other variables and each variable has two levels (Fraenkel, Wallen, \& Hyun, 2012). In this study, both instructional treatment (guided inquiry approach and traditional recipe-like approach) and learning environment (authentic and virtual environment) had two levels. Participants were stratified into four groups and $2 \times 2$ factorial design, in which the instructional treatment and learning environment were adopted as independent variables, was used (Table 3). Guided inquiry-based laboratory activities were conducted in AIL and VIL in the authentic and virtual environments, respectively. VRL and ARL performed traditional recipe-like laboratory activities in the virtual environments and authentic environments, respectively. Instructions in all groups were conducted during eight weeks and the GCCT was applied before and after the instructions.

Table 3. Research design used in the study

\begin{tabular}{llcc}
\hline & & \multicolumn{2}{c}{ Learning environment } \\
\cline { 3 - 4 } & & Authentic Laboratory (AL) & Virtual Laboratory (V) \\
\hline Instructional & Guided Inquiry Approach (GIA) & Authentic Inquiry-based Laboratory & Virtual Inquiry-based Laboratory \\
\cline { 2 - 4 } treatment & Recipe-like Approach (RA) & Authentic Recipe-like Laboratory & Virtual Recipe-like Laboratory \\
\hline
\end{tabular}




\section{Instructional Treatment}

In the present study, eight laboratory activities related to chemical kinetics, chemical equilibrium, thermochemistry, acids-bases and electrochemistry were developed (Table 4).

Table 4. Distribution of laboratory activities according to subjects

\begin{tabular}{cll}
$\begin{array}{c}\text { Number of } \\
\text { Experiment }\end{array}$ & Subjects & Aim of laboratory activities \\
\hline 1 & Chemical Kinetics & $\begin{array}{l}\text { Identification of effect of surface, temperature, stirring and amount of substance on } \\
\text { reaction rate }\end{array}$ \\
\hline 2 & Chemical Kinetics & Identification of the effect of catalyst on reaction rate \\
\hline 3 & Chemical Equilibrium & Identification of the effect of temperature and concentration on equilibrium reaction \\
\hline 4 & Thermochemistry & Identification of heats of dissolution and neutralization \\
\hline 5 & Acids and Bases & To calculate the degree of acidity by titration \\
\hline 6 & Acids and Bases & To comprehend the buffer mechanism \\
\hline 7 & Electrochemistry & Identification of the effect of concentration on cell potential \\
\hline 8 & Electrochemistry & Identification of the ways of removing rust and corrosion prevention \\
\hline
\end{tabular}

In the first step of developing the laboratory activities, the literature was reviewed and the pre-service science teachers' understanding and learning difficulties were determined. After the learning objectives were identified, the laboratory activities were prepared properly for both guided-inquiry-based and traditional recipe-like approaches. Before the instruction, all the pre-service science teachers were informed about the learning process with a brief orientation including group rules, student and instructor roles, and assessment criteria. All the preservice science teachers conducted the same laboratory activities in a different manner under the guidance of the instructor. While the pre-service science teachers in the authentic laboratory environment performed physical manipulation of equipments themselves under the guidance of an instructor, the pre-service science teachers in the virtual environment virtually complete this process as if they were in an authentic laboratory environment.

Authentic Inquiry-based Laboratory. The pre-service science teachers $(N=17)$ were randomly assigned to four cooperative groups for conducting the laboratory activities based on the guided-inquiry approach in an authentic laboratory laboratory environment. In addition, laboratory worksheets were prepared according to the stages of the inquiry-based laboratory activity mentioned by Hofstein, Shore and Kipnis (2004). These worksheets had two phases and seven steps, which are presented in Table 5.

Table 5. Laboratory worksheets based on guided-inquiry approach in this study

\begin{tabular}{|c|c|c|}
\hline Phases & Steps & Pre-service science teachers' requirements \\
\hline Pre-inquiry & $\begin{array}{l}\text { A brief story about daily life, } \\
\text { connected with the learning issues }\end{array}$ & $\begin{array}{l}\text { Read the story in a detailed manner, to discuss and inquire the situation given in } \\
\text { the story }\end{array}$ \\
\hline \multirow{6}{*}{ Inquiry } & Define your problem & Define the problem given in the story \\
\hline & Define your hypothesis & $\begin{array}{l}\text { Define hypothesis/hypotheses for the solution of the problem situation given in } \\
\text { the story }\end{array}$ \\
\hline & Collect data & $\begin{array}{l}\text { Design an experiment to prove the hypothesis by using laboratory } \\
\text { materials/chemicals that were given in worksheets or the others that you want } \\
\text { to use. }\end{array}$ \\
\hline & Write your experimental steps & $\begin{array}{l}\text { Write the experimental procedures for the experiment planned by the pre- } \\
\text { service science teachers. }\end{array}$ \\
\hline & Results & $\begin{array}{l}\text { Write the results obtained from the experiment. In addition, draw a graph and } \\
\text { present tables for results (if it is necessary) }\end{array}$ \\
\hline & Interpretation & $\begin{array}{l}\text { Interpret findings and associate them with the problem and hypothesis. If the } \\
\text { hypothesis is not proved by the results, the experiment needs to be re-planned } \\
\text { and re-done in this step }\end{array}$ \\
\hline
\end{tabular}

All worksheets were reviewed by four chemistry educators, and they were piloted by the participation of five pre-service science teachers. Unless the instructor confirmed the pre-service science teachers' writings, they could not pass onto the next step.

As an example, the schematic representation of a guided-inquiry-based laboratory activity worksheet, related to chemical equilibrium topic, is presented in Figure 1. The purpose of the activity was the identification of the effect of temperature and concentration on the equilibrium reaction. In this activity, a brief daily life story was given to the pre-service science teachers. The story was about solving a problem based on a laboratory accident. In the story, a student prepared $\mathrm{CoCl}_{2}$ and $\mathrm{HCl}$ solution and she poured $\mathrm{HCl}$ onto $\mathrm{CoCl}_{2}$, accidently. Then, she observed that solution's colour turned from pink to blue. So, the pre-service science teachers inquired other ways of turning the solution's colour from pink to blue and from blue to pink as mentioned in the story. 


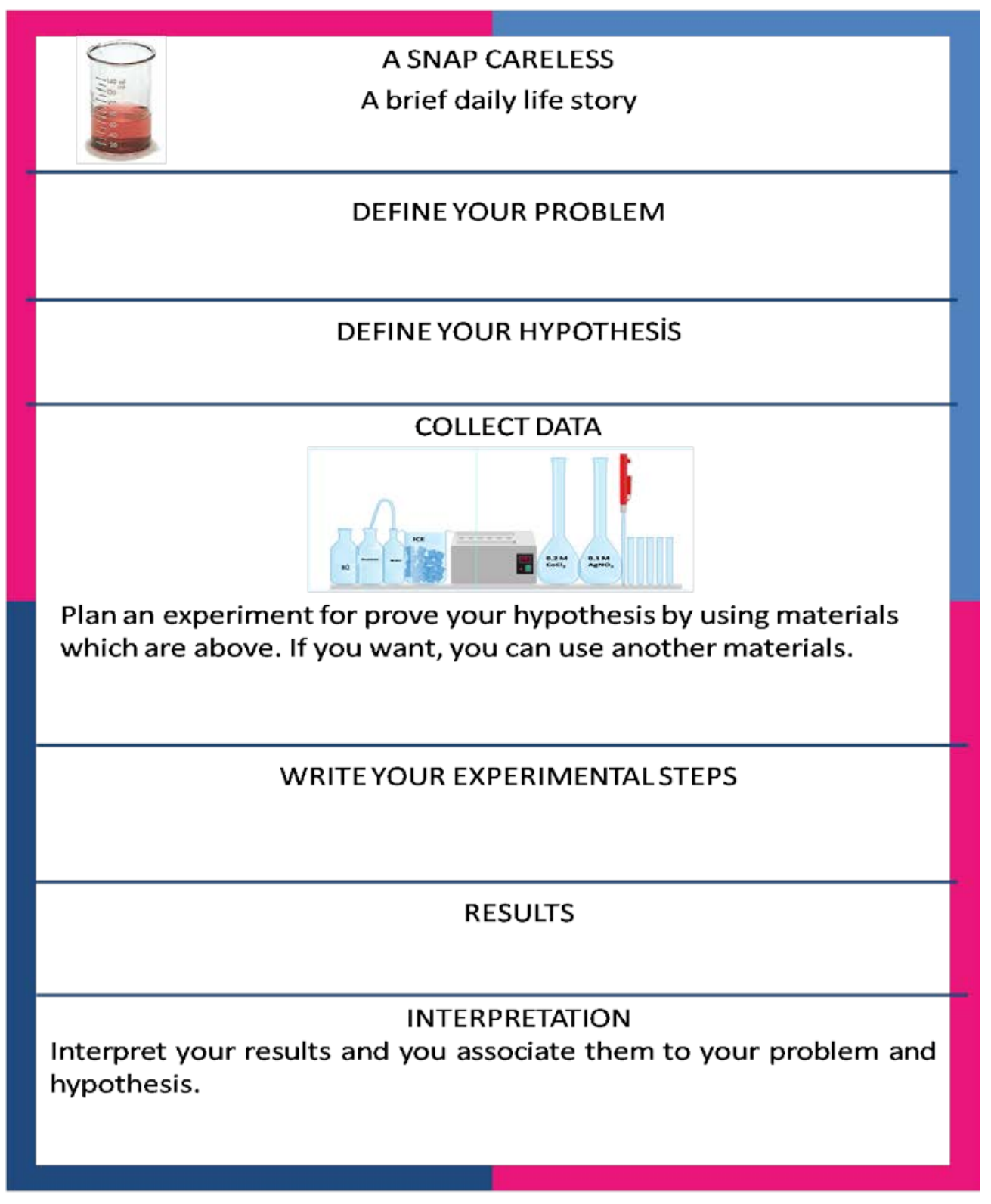

Figure 1. A schematic representation of the worksheet

In this story, the reason for choosing a reaction that changed colour by effects was making concrete the effects on equilibrium. During the discussion in all the steps of the activity, the instructor was a guide to prevent misleading the pre-service science teachers. In the first step of this activity, the pre-service science teachers read and discuss the story. In the second step, they were required to define the problem given in the story. In this step, they first discussed the type of reaction given in the story. After they had identified the reaction type as an equilibrium reaction, they discussed the reason for the colour change. After the discussion, the pre-service science teachers were required to identify the problem situation, what other ways of colour changing in this equilibrium reaction. In the context of the problem, they actually discovered factors affecting equilibrium. After confirmation of the problem, they defined their hypothesis in the third step and they planned an experiment related to chemical equilibrium to prove their hypothesis. In this step, concentrated $\mathrm{HCl}$, acetone, water, ice, water bath, $0.2 \mathrm{M} \mathrm{CoCl}_{2}$, $0.1 \mathrm{M} \mathrm{AgNO}_{3}$, some pipettes and some test tubes were given to the pre-service science teachers and they were required to design an experiment using these materials or the other laboratory materials and chemicals that they wanted. Then, they carried out the experiment. They had an opportunity to observe the effects of temperature and concentration on equilibrium reaction of $\mathrm{CoCl}_{2}$ and $\mathrm{HCl}$. During the activity, they recorded their observations and findings in their worksheet. Lastly, they discussed their findings, they associated their results with the problem and hypothesis defined at the beginning of the activity and they shared the results with their classmates. 
Virtual Inquiry-based Laboratory. The pre-service science teachers $(N=17)$ were randomly stratified into four groups for conducting the laboratory activities based on the guided-inquiry approach in a virtual laboratory environment. In the present study, two software programs were developed: Guided-Inquiry-based Virtual Chemistry Laboratory (GIBVL) software for the pre-service science teachers and Instructor Software for the instructor. In GIBVL, the same guided-inquiry based laboratory activities as in AIL were computerized to a virtual environment. In addition, GIBVL was developed based on the Analysis, Design, Development, Implementation, and Evaluation (ADDIE) instructional design model (Table 6).

Table 6. Development process of GIBVL based on ADDIE model

Steps of the model Implementations
Basic properties of GIBVL and development standards were identified.
Experiments were conducted in a real environment and they were recorded for identification of software
content, steps of experiments and real experimental data.
Virtual laboratory applications were examined.
Web sites and books were examined for modelling the software interfaces, experimental materials and
equipment.
Use of HTML5, CSS3, PHP, MySQL, Adobe Flash Action Script 3.0, jQuery programs and applications were
decided.

The pre-service science teachers carried out guided-inquiry-based virtual laboratory activities using GIBVL. These virtual activities had the same steps as AIL, in which there was a brief story about daily life, defining the problem, defining the hypothesis, collecting data, writing experimental steps, results and interpretation. In addition, the instructor confirmed or refused the pre-service science teachers' problem, hypothesis etc. using instructor software. Unless the instructor confirmed their writings, learners could not pass on to the following step.

Moreover, the instructor could send short guiding sentences about accomplishing steps and the reason for their refusals. So, the pre-service science teachers had an opportunity to communicate with the instructor and correct their errors in this way.

As an example, a GIBVL activity related to the chemical equilibrium topic is presented in Figure 2. A brief daily life story which was the same as in AIL was given at the beginning of this activity. After the pre-service science teachers had read the story, they were steered to define the problem and send it to the instructor software. The preservice science teachers sent their writing to the instructor software; the instructor could confirm or refute it. After the pre-service science teachers' problems and hypothesis had been confirmed by the instructor, they were required to plan an experiment. After the instructor had confirmed the pre-service science teachers' plan of the experiment, they were steered to conduct the experiment planned by them. After the pre-service science teachers had completed each level of the experiment, they were required to take notes, such as steps of the experiment, their observation or findings on the notepad in GIBVL. Unless they took notes, they could not move on to the next step of the experiment. So, they were encouraged to take notes in this way. At the end of the activity, the pre-service science teachers were steered to send their results to the instructor to be confirmed. If their results were refused, they could repeat step/steps that they wanted. After their results had been confirmed, they associated their results with their problem and hypothesis and they sent it back to the instructor to be confirmed. After the confirmation, they could complete the activity. 

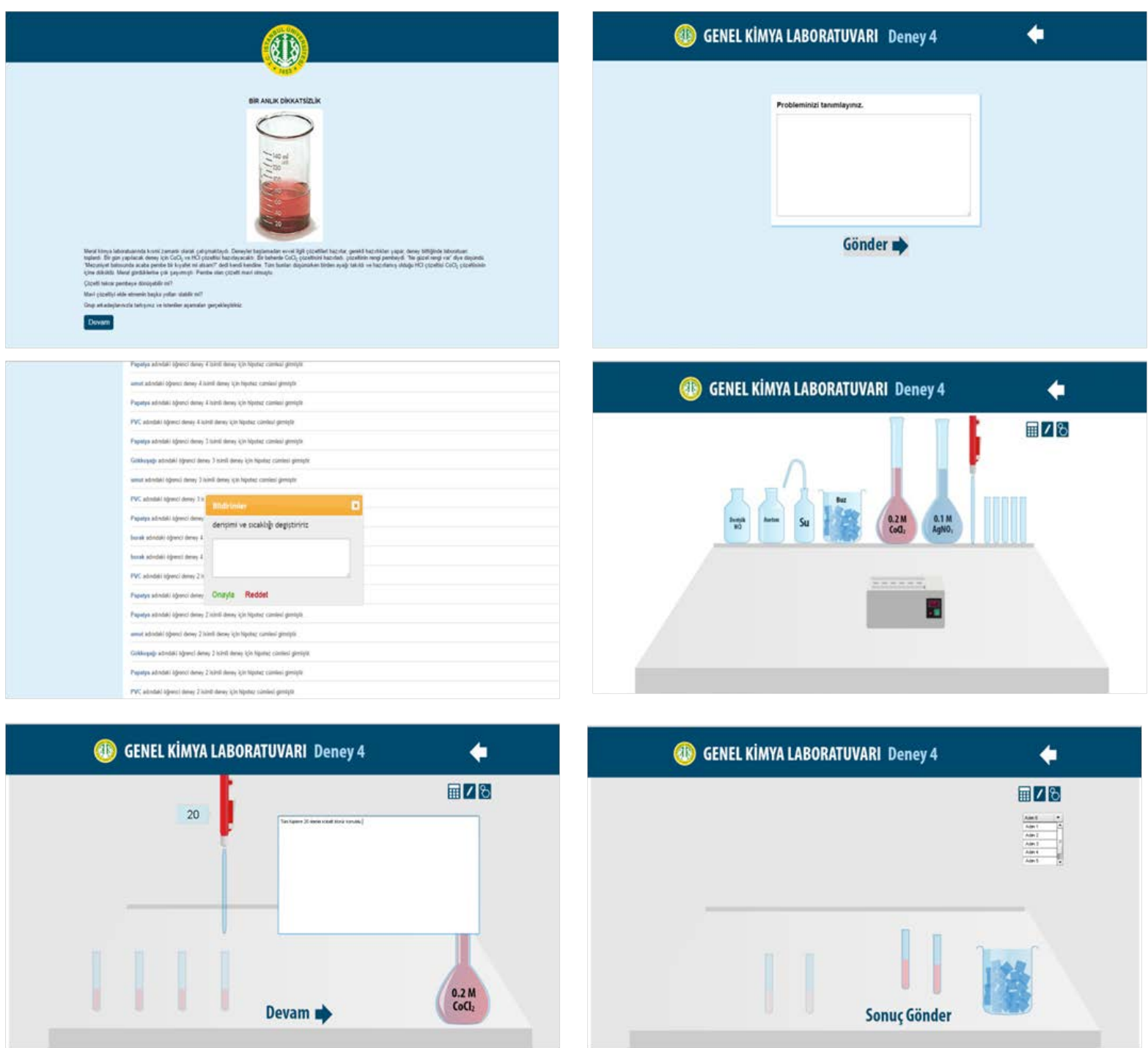

Figure 2. Interface of different steps in guided-inquiry based virtual laboratory

Virtual Recipe-like Laboratory. In VRL $(N=17)$, the pre-service science teachers were randomly stratified into four groups for conducting the laboratory activities based on a traditional recipe-like approach in a virtual laboratory environment. For this purpose, traditional recipe-like learning approach based virtual chemistry laboratory software (TABVL) was developed. While TABVL was being developed, the same procedure that had been used to develop GIBVL was conducted according to the ADDIE instructional model (Table 7). 
Table 7. Development process of TABVL based on the ADDIE model

\begin{tabular}{ll}
\hline $\begin{array}{l}\text { Steps of the } \\
\text { model }\end{array}$ & Implementations \\
\hline & Basic properties of TABVL and development standards were identified. \\
Experiments were conducted in a real environment and they were recorded for identification of software \\
content, steps of experiments and real experimental data. \\
Virtual laboratory applications were examined. \\
Web sites and books were examined for modelling the software interfaces, experimental materials and \\
equipment. \\
Use of HTML5, CSS3, PHP, MySQL, Adobe Flash Action Script 3.0, jQuery programs and applications were \\
decided.
\end{tabular}

In TABVL, the same laboratory activities were conducted with AIL and VIL. However, experiments directly began in this software and the pre-service science teachers carried out these experiments by following the laboratory guide step by step.

A TABVL activity related to the chemical equilibrium topic is presented in Figure 3.

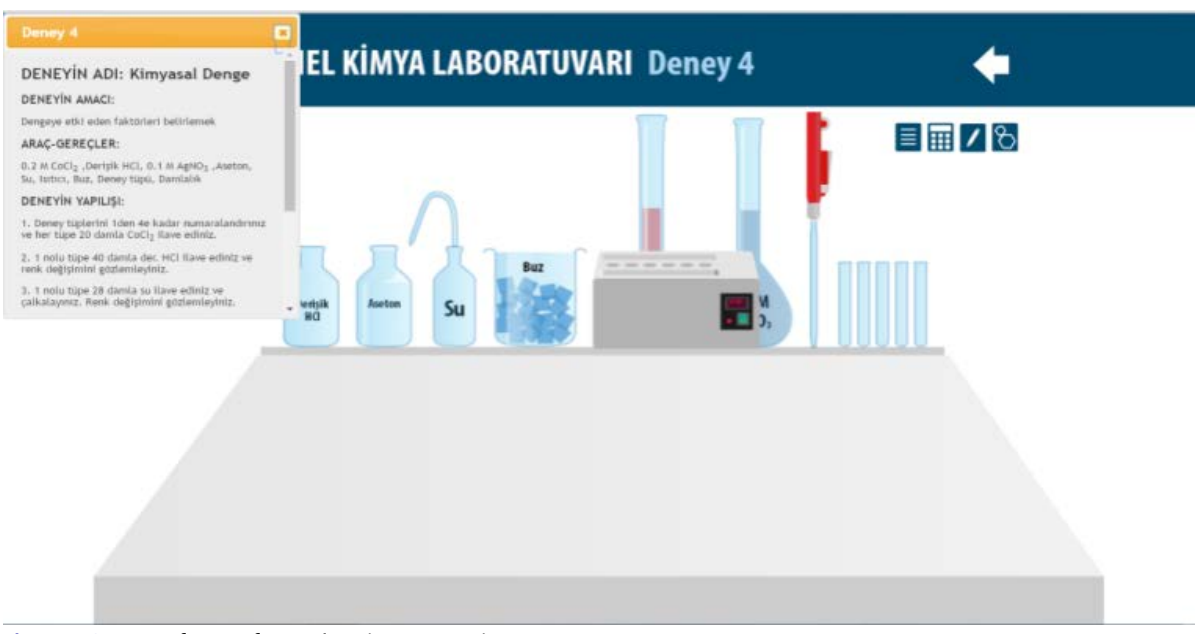

Figure 3. Interface of conducting experiment

In this activity, the pre-service science teachers began the experiment directly. At the beginning of the activity, the pre-service science teachers were steered to read the laboratory guide in TABVL. They followed the laboratory guide step by step during the experiment. In addition, they were required to take notes about their observations and findings during the experimental process as in GIBVL.

Authentic Recipe-like Laboratory.In ARL $(N=17)$, the pre-service science teachers were randomly stratified into four groups for conducting the laboratory activities based on the traditional recipe-like approach in an authentic laboratory environment. For this purpose, laboratory guides based on the traditional recipe-like approach were prepared for each activity. In these laboratory guides, the name of the experiment, the aim of the experiment, 
a list of materials and chemicals and steps of the experiment were presented to the pre-service science teachers. In addition, they could write their observations and findings on to these guides.

As an example, a schematic representation of a laboratory guide related to the chemical equilibrium topic is presented in Figure 4.

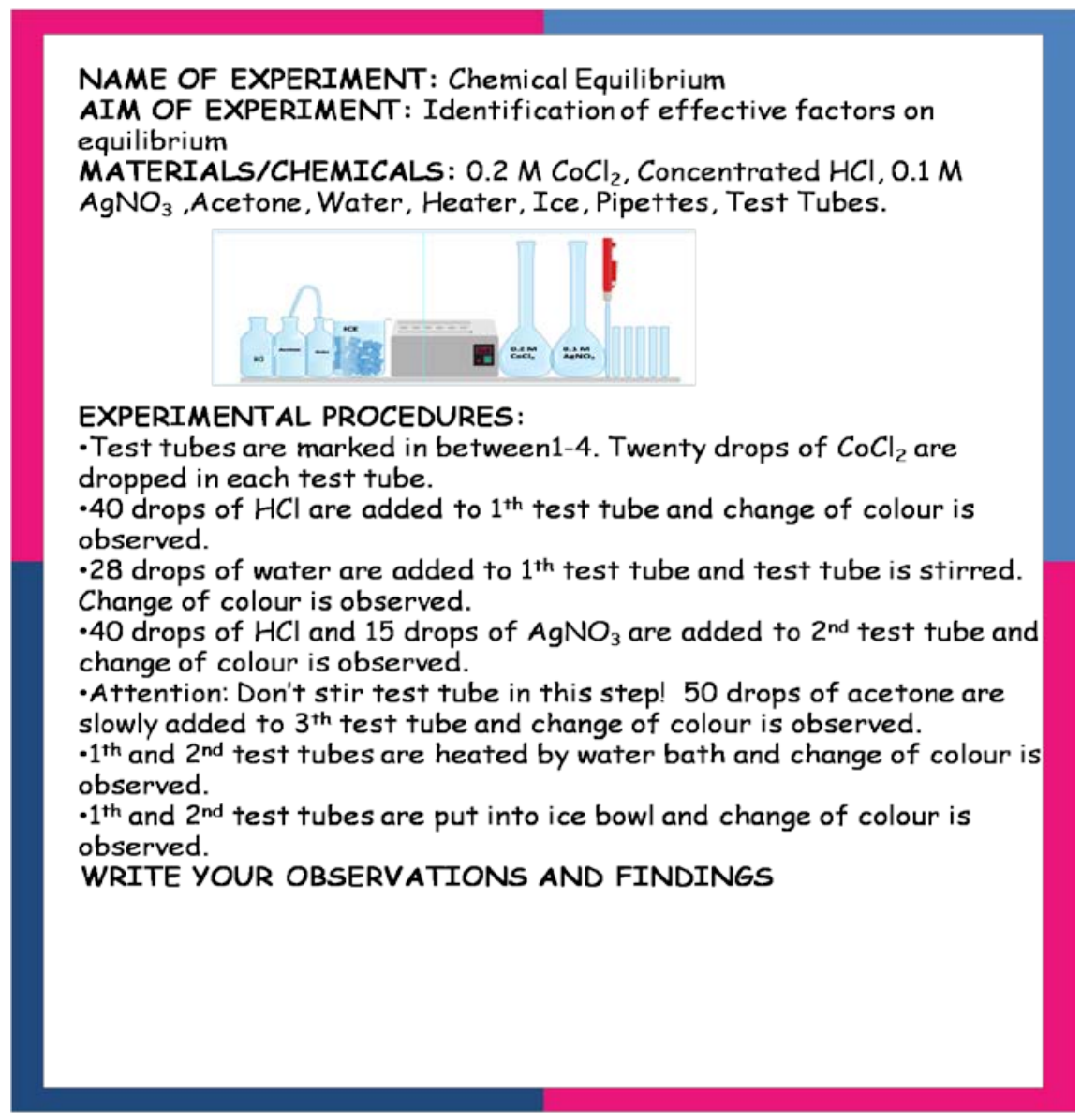

Figure 4. Schematic representation of a laboratory guide related to the chemical equilibrium topic

In this activity, the pre-service science teachers were required to follow these laboratory guides step by step. Therefore, they read the guide clearly and they prepared the laboratory materials and chemicals as given in it. While they were conducting the experiment, they took notes about their observations and findings in the laboratory guide.

\section{Data Analysis}

While the GCCT was being analysed, the total score was first calculated. For this purpose, each item was considered to be correctly answered if first tier and second tier were correctly chosen (Treagust, 1988). Therefore, one point was given for items only when both parts of the item were correctly answered, and zero points were given for items when either part was incorrectly answered. This scoring made possible the decreasing of the percentage of students' obtaining a correct answer by chance (Tsui \& Treagust, 2010) and evaluated meaningful understanding, deeply.

The pre-test and post- test mean scores of all the groups were compared using nonparametric statistical methods, Kruskal-Wallis H, Mann Whitnet-U and Wilcoxon Signed Ranks, because the actual size of the population is small. The Bonferroni adjustment was also used for Mann-Whitney U test and a was calculated as 0.0083 by split 0.05 to six (Green \& Salkind, 2005). The effect size was calculated for comparison by using $r=z \sqrt{N}$ (Pallant, 2007).

In addition, each item of the GCCT was analysed by the following Treagust method (1988) for identifying the pre-service science teachers' alternative conceptions and conceptual change. For this reason, the frequency of each option in the GCCT was calculated in the pre-test for each group and alternative conceptions were identified. Then, these alternative conceptions were examined in the post-test and their frequency variation was reported. 
An example item related to acids and bases is presented to illustrate how the item worked and how the data were analysed by the researcher by the following Treagust method (1988).

Which of the following is true about indicators?

a) They increase the rate of reaction.

b) They decrease the rate of reaction.

c) They are strong acid or base.

d) They are weak acid or base.

BECAUSE;

A) They provide colour change by neutralization of acid or base.

B) Indicators provide an alternative way for the reaction to happen which has a lower activation energy.

C) When acid or base are added, they can change colour in different $\mathrm{pH}$ range because they give equilibrium reaction based on changing of colour.

D) They decrease the yield of reaction by disrupting the reactants' structures.

E) They increase activation energy of the reaction.

This item assessed the pre-service science teachers' understanding of indicators and their mechanism. While this item was analysed, the frequency (f) of each option of the item was calculated in the pre-test (Table 8).

Table 8. Analysis of an acids and bases-related item in the pre-test for identifying the pre-service science teachers' understanding in AIL

\begin{tabular}{|c|c|c|c|c|c|c|c|}
\hline \multirow[t]{2}{*}{$\mathbf{N}$} & \multirow{2}{*}{ First Tier (f) } & \multicolumn{6}{|c|}{ Second Tier (f) } \\
\hline & & $\mathbf{A}$ & B & C & D & $\mathbf{E}$ & No reason \\
\hline \multirow{6}{*}{17} & $a(2)$ & - & - & - & - & - & 2 \\
\hline & $b(11)$ & - & 6 & 2 & - & - & 3 \\
\hline & $c(0)$ & - & - & - & - & - & \\
\hline & d (3) & - & - & $1^{*}$ & - & - & 2 \\
\hline & No choice (1) & - & - & - & - & - & 1 \\
\hline & Total & - & 6 & 3 & - & - & 8 \\
\hline
\end{tabular}

Note * The correct choice and reason response

- No responses in this category

Most of the pre-service science teachers in AIL (8) gave no response. A small part of the pre-service science teachers in AIL correctly responded to the first tier 'They are a weak acid or base'. In addition, some of the preservice science teachers in AIL (3) correctly responded to the second tier. However, only one pre-service science teacher selected the correct choice for each tier: (d) for the first tier and (C) for the second tier. Moreover, two of the three pre-service science teachers who selected the correct answer in the first tier gave no reason in the second tier. So, only one pre-service science teacher correctly understood indicators and some of their features. In addition, two pre-service science teachers selected choice (a) and 11 pre-service science teachers selected choice (b) in the first tier and six pre-service science teachers selected choice (B) in the second tier, respectively. According to the results, the following alternative conceptions about indicators were determined in the pre-test:

Indicators increase the rate of reaction $(f=2)$.

Indicators decrease the rate of reaction $(f=11)$.

Indicators provide an alternative way for the reaction to happen which has a lower activation energy $(f=6)$.

In addition, the variation of these alternative conceptions' frequencies was calculated in the post-test to assess the pre-service science teachers' understanding and conceptual change. For this purpose, the options that included these alternative conceptions were examined in the post-test and their frequencies were reported (Table 9). The pre-test and post-test of all groups were analysed in similar ways and findings are presented in the Results and Discussion section.

Table 9. Understanding of the pre-service science teachers in AlLabout indicators

\begin{tabular}{lcc}
\hline Alternative Conceptions & Pre-test $(\boldsymbol{f})$ & Post-test $(\boldsymbol{f})$ \\
\hline Indicators increase the rate of reaction. & 2 & 2 \\
\hline Indicators decrease the rate of reaction. & 11 & 1 \\
\hline $\begin{array}{l}\text { Indicators provide an alternative way for the reaction to happen which has a lower } \\
\text { activation energy. }\end{array}$ & 6 \\
\hline
\end{tabular}




\section{RESULTS AND DISCUSSION}

The GCCT was applied before and after the instructions as in pre-test and post-test. The descriptive statistics of the pre-test and post-test GCCT are presented in Table 10.

Table 10. Descriptive Statistics of the Pre-test and Post-test GCCT

\begin{tabular}{cccccc}
\hline Group & Test & Mean & Standart Devision & Minimum Score & Maximum Score \\
\hline \multirow{2}{*}{ AIL } & Pre Test & 8.76 & 3.73 & 5.00 & 16.00 \\
\cline { 2 - 6 } & Post Test & 15.29 & 4.36 & 7.00 & 27.00 \\
\hline \multirow{2}{*}{ VIL } & Pre Test & 8.82 & 3.49 & 5.00 & 15.00 \\
\cline { 2 - 6 } & Post Test & 15.06 & 2.70 & 12.00 & 22.00 \\
\hline \multirow{2}{*}{ VRL } & Pre Test & 8.71 & 2.73 & 8.00 & 12.00 \\
\cline { 2 - 6 } & Post Test & 12.65 & 3.24 & 4.00 & 12.00 \\
\hline \multirow{2}{*}{ ARL } & Pre Test & 7.94 & 2.51 & 6.00 & 16.00 \\
\cline { 2 - 6 } & Post Test & 9.59 & 2.94 & \\
\hline
\end{tabular}

In order to compare pre test and post test scores of groups, Kruskal Wallis H Test was used (Table 11).

Table 11. Kruskal Wallis H Test Results

\begin{tabular}{|c|c|c|c|c|c|c|}
\hline Test & Group & $\mathbf{N}$ & Mean Rank & sd & $x^{2}$ & $p$ \\
\hline \multirow{4}{*}{ Pre test } & AlL & 17 & 34.53 & 3 & 0.618 & 0.892 \\
\hline & VIL & 17 & 35.59 & & & \\
\hline & VRL & 17 & 36.41 & & & \\
\hline & ARL & 17 & 31.47 & & & \\
\hline \multirow{4}{*}{ Post test } & AIL & 17 & 44.65 & 3 & 24.382 & 0.000 \\
\hline & VIL & 17 & 45.47 & & & \\
\hline & VRL & 17 & 31.35 & & & \\
\hline & ARL & 17 & 16.53 & & & \\
\hline
\end{tabular}

According to Kruskall Wallis H Test Results, while there was no significant difference between pre-test scores of groups $[x 2(s d=3, n=17)=0.618, p>0.05]$, there was significant difference between post test scores of groups $\left[x^{2}(\mathrm{sd}=3, \mathrm{n}=17)=24.382, \mathrm{p}<0.05\right]$. For identification of differences between post test score of groups Mann Whitney $\mathrm{U}$ test were conducted (Table 12).

Table 12. Mann Whitney U Test Results

\begin{tabular}{cccccc}
\hline Group & $\mathbf{N}$ & Mean Ranks & Sum of Ranks & $\mathbf{U}$ & $\mathbf{p}$ \\
\hline AIL & 17 & 17.62 & 299.50 & 142.500 & 0.945 \\
\hline VIL & 17 & 17.38 & 295.50 & & 0.034 \\
\hline AIL & 17 & 21.09 & 358.50 & 83.500 & \\
\hline VRL & 17 & 13.91 & 236.50 & 35.000 & 0.000 \\
\hline AIL & 17 & 23.94 & 407.00 & & 0.017 \\
\hline ARL & 17 & 11.06 & 188.00 & 76.000 & 0.000 \\
\hline VIL & 17 & 21.53 & 366.00 & 24.500 & \\
\hline VRL & 17 & 13.47 & 229.00 & 68.500 & 0.009 \\
\hline VIL & 17 & 24.56 & 417.50 & & \\
\hline ARL & 17 & 10.44 & 373.50 & & \\
\hline VRL & 17 & 21.97 & 221.50 & & \\
\hline ARL & 17 & 13.03 & & &
\end{tabular}

According to results with Bonferroni Adjustment, it was found significant difference between AIL and ARL $(\mathrm{U}=35.000, \mathrm{z}=-3.787, \mathrm{p}<0.0083, \mathrm{r}=0.65)$, VIL and ARL $(\mathrm{U}=24.500, \mathrm{z}=-4.153, \mathrm{p}<0.0083, \mathrm{r}=0.71)$. Lastly, Wilcoxon Signed Rank Test was used for comparing pre-post test scores of groups (Table 13). 
Table 13. Wilcoxon Signed Ranks Test Results

\begin{tabular}{|c|c|c|c|c|c|c|}
\hline Group & Post Test-Pre Test & $\mathbf{N}$ & Mean Ranks & Sum of Ranks & $z$ & $\mathbf{P}$ \\
\hline \multirow{3}{*}{ AIL } & Negative Rank & 0 & 0.00 & 0.00 & $-3.628^{*}$ & 0.000 \\
\hline & Positive Rank & 17 & 9 & 153.00 & & \\
\hline & Ties & 0 & - & & & \\
\hline \multirow{3}{*}{ VIL } & Negative Rank & 0 & 0.00 & 0.00 & $-3.625^{*}$ & 0.000 \\
\hline & Positive Rank & 17 & 9 & 153.00 & & \\
\hline & Ties & 0 & - & & & \\
\hline \multirow{3}{*}{ VRL } & Negative Rank & 0 & 0.00 & 0.00 & $-3.634^{*}$ & 0.000 \\
\hline & Positive Rank & 17 & 9 & 153.00 & & \\
\hline & Ties & 0 & - & & & \\
\hline \multirow{3}{*}{ ARL } & Negative Rank & 3 & 8.00 & 24.00 & $-2.062^{*}$ & 0.039 \\
\hline & Positive Rank & 12 & 8.00 & 96.00 & & \\
\hline & Ties & 2 & - & & & \\
\hline
\end{tabular}

*Based on negative ranks

As shown in the Table 13, there was significant difference between pre-test and post test scores after instructions of the Authentic Inquiry-based Laboratory $(z=3.628, p<0.05, r=0.62)$, Virtual Inquiry-based Laboratory $(z=3.625$, $\mathrm{p}<0.05, \mathrm{r}=0.62)$, Virtual Recipe-like Laboratory $(\mathrm{z}=3.634, \mathrm{p}<0.05, \mathrm{r}=0.62)$, Authentic Recipe-like Laboratory $(\mathrm{z}=2.062$, $\mathrm{p}<0.05, \mathrm{r}=0.35)$.

To evaluate the pre-service science teachers' understanding and conceptual change, their responses to each item were analysed and the percentage of the pre-service science teachers' choices for each option was calculated. Alternative conceptions determined in this study are presented in the Appendix. According to the findings, the pre-service science teachers had 83 alternative conceptions (Chemical kinetics: 18, chemical equilibrium: 7, thermochemistry: 9, acids and bases: 37 and electrochemistry: 12). These alternative conceptions were classified under subheadings and these subheadings were reaction rate, concentration effect, reaction rate constant, surface area effect, catalyst effect, reaction mechanism, temperature effect, collision theory; Le Chatelier's Principle, temperature effect, equilibrium constant; endothermic reactions, reaction enthalpy, bond energy, exothermic reactions, neutralization heat; titration, strength of acids and bases, indicators, neutralization, equivalence point, acid-base equilibrium, buffer solutions, cell potential, metal electrodes, galvanization and plating, anode-cathode before the instruction. The frequency of each alternative conception changed different ratios after the instruction. The results indicated that the frequencies of alternative conceptions identified in the pre-test, decreased in the posttest. Decreasing of frequencies of alternative conceptions was arranged in the order Authentic Inquiry-based Laboratory (AIL), Virtual Inquiry-based Laboratory (VIL), Virtual Recipe-like Laboratory (VRL) and Authentic Recipe-like Laboratory (ARL) except for chemical kinetics topics. This result may be because the pre-service science teachers in ARL were instructed the first topic in their current learning environment based on a traditional recipelike laboratory approach; the other groups were trained in different learning environments for the first time. In view of this, it was thought that the pre-service science teachers in VRL, VIL and AIL focused on their new learning environments rather than the learning issue. For this reason, their alternative conceptions could not be remedied as was required.

According to the results, the influence of instructional treatment on understanding depends on whether the learning environment was authentic or virtual. Therefore, the influence of instructional treatment on understanding is different for authentic and virtual environments. For example, while the instructional treatment of AIL and VIL was a guided-inquiry-based learning approach; AIL had higher mean score than VIL in the post-GCCT. Similarly, while the instructional treatment of VRL and ARL was the traditional recipe-like approach, VRL had higher mean score than ARL in the post-GCCT. It was also found that mean scores of groups were arranged in the order AIL, VIL, VRL and ARL. These results indicated that the pre-service science teachers' conceptual understanding was better for the authentic inquiry-based laboratory environment than for the virtual inquiry-based laboratory environment and virtual recipe-like experiment than for the authentic recipe-like experiment. In addition, the guided-inquiry-based learning approach was more effective than the traditional recipe-like approach in promoting the pre-service science teachers' conceptual understanding. The pre-service science teachers achieved knowledge themselves using their high level thinking skills such as formulating a hypothesis, planning an experiment, interpreting and inquiring findings in the inquiry based learning environment. In addition, the pre-service science teachers only followed their recipes for conducting an experiment, they did not achieve new knowledge themselves and they only proved it in the traditional recipe-like environment. In the literature, research has compared the inquiry-based learning approach with the traditional approach and they agree with the results of the present study (e.g. Akben, 2015; Almuntasheri, Gillies, \& Wright, 2016; Buckner \& Kim, 2014; Franklin et al., 2015; Hemraj-Benny \& Ian Beckford, 2014; Hsiao et al., 2017; Kaya \& Yilmaz, 2016; Ozkan \& Bumen, 2014; Ramnarain, 2014; Yetişir, 2016). Although the learning environments of VIL and VRL were virtual laboratories, VIL had no significantly 
higher mean score than VRL in post-GCCT. This situation can be explained as the effect of the guided-inquirybased approach. In addition, the pre-service science teachers in VIL had an opportunity to communicate with their instructor during the instruction by GIBVL software. These properties make them more active. In addition, feedback gave them a chance to correct their mistakes. These situations can be effective in the understanding of the pre-service science teachers. In previous research, it was underlined that the interactive virtual laboratory provided an effective action-reaction process and learning became more meaningful in this way (Ozdener, 2005; Tatli, 2011; Trindade et al., 2002).

Although instructional treatments of VRL and ARL were based on a traditional recipe-like approach, VRL had no significantly higher mean score than ARL in the post-GCCT. This situation can be explained by the effects of the virtual environment. The pre-service science teachers got used to conducting an experiment based on the traditional recipe-like approach because virtual experiments were different and interesting for the pre-service science teachers in VRL. Therefore, the pre-service science teachers in VRL focused more on the learning issue. Although virtual environments had different and interesting content and contributed to conceptual understanding by providing different learning environment experience, previous research that compared a real laboratory with a virtual laboratory had different results. Some of this research indicated that virtual laboratory instruction was more effective than traditional laboratory instruction in promoting conceptual understanding (Bakar \& Zaman 2007; Bozkurt, 2008; Kennepohl, 2001; Tatli, 2011; Tuysuz, 2010). On the other hand, Bernard et al. (2004) and Cavanaugh et al. (2004) found that there was no difference between the contributions of virtual and traditional laboratories to students' achievement. In addition, some of the virtual laboratory research emphasized that virtual laboratories had some limitations, such as interaction with laboratory materials and chemicals (Bucos et al., 2008), improving skills in this way (Carnevale, 2003; Diker, 2011).

\section{CONCLUSIONS}

The aim of the present study was to investigate the effect of four different learning environments, Authentic Inquiry-based Laboratory, Virtual Inquiry-based Laboratory, Authentic Recipe-like Laboratory and Virtual Recipelike Laboratory, on the pre-service science teachers' understanding of chemistry concepts. According to the results, the Authentic Inquiry-based Laboratory was the most effective learning environment for the pre-service science teachers' understanding and remedying of alternative conceptions except for chemical kinetics and the least effective one was the authentic recipe-like laboratory. For the instructional treatment, the guided-inquiry-based approach was more effective than the traditional recipe-like approach both authentic and virtual environments. For the learning environment, while the authentic environment was more beneficial than the virtual environment when it was supported by guided-inquiry-based learning; the virtual environment was more effective than the authentic environment when it was based on the traditional recipe-like approach. However, the virtual environment had the best effect when it was supported by guided-inquiry-based learning.

In the light of results of research, it was concluded that guided-inquiry-based learning can be used in both authentic and virtual laboratories for improving conceptual understanding of chemistry concepts. In brief, if the learning environment is supported by the appropriate learning approach, it will be effective. A virtual laboratory can be preferred as an alternative to the authentic laboratory when dangerous, expensive or long experiments are conducted or there is no laboratory in the school. However, it was suggested that if virtual laboratory is used, it should be supported by active learning approach such as guided-inquiry-based learning. In addition, because students could not use their psychomotor skills in a virtual laboratory as mentioned by previous research, the authentic laboratory should be preferred by instructors.

\section{REFERENCES}

Akben, N. (2015). The Effect of Open Inquiry-Based Laboratory Activities on Prospective Teachers' Misconceptions about Matter. International Online Journal of Educational Sciences, 7(3), 164-178. https:/ / doi.org/10.15345/iojes.2015.03.003

Almuntasheri, S., Gillies, R. M., \& Wright, T. (2016). The Effectiveness of a Guided Inquiry-Based, Teachers' Professional Development Programme on Saudi Students' Understanding of Density. Science Education International, 27(1), 16-39.

Altun, E. H., Feyzioglu, B., \& Demirag, B. (2011). Development of Interactive Virtual Chemistry Laboratory Enriched by Constructivist Learning Activities for High School. TUBITAK, Project number: 108K293.

Altun, E., Demirdag, B., Feyzioglu, B., Ates, A. \& Cobanoglu, I. (2009). Developing an Interactive Virtual Chemistry Laboratory Enriched With Constructivist Learning Activities For Secondary Schools. Procedia-Social and Behavioral Sciences, 1(1), 1895-1898. https:/ / doi.org/10.1016/j.sbspro.2009.01.333 
Bakar, H. N. B., \& Zaman, H. H. B. (2007). Development of VLab-Chem for Chemistry Subject Based On ConstructivismCognitivism-Contextual Approach. Paper Presented at the International Conference on Electrical Engineering and Informatics, Indonesia.

Bernard, R. M., Abrami, P. C., Lou, Y., Borokhovski, E., Wade, A., \& Wozney, L. (2004). How Does Distance Education Compare with Classroom Instruction? A Meta Analysis of the Empirical Literature. Review of Educational Research, 74(3), 379-439. https://doi.org/10.3102/00346543074003379

Bozkurt, E. (2008). The Effect on Students' Success of a Virtual Laboratory Application Prepared in the Physics Education (PhD Dissertation), University of Selcuk.

Buckner, E., \& Kim P. (2014). Integrating technology and pedagogy for inquiry-based learning: The Stanford Mobile Inquiry-based Learning Environment (SMILE). Prospects, 44(1), 99-118. https://doi.org/10.1007/s11125013-9269-7

Bucos, M. C., Dragulescu, B., \& Ternauciuc, A. (2008). Developing Virtual Labs at "Politehnica" University of Timisoara. Paper Presented at the Interactive Conference on Computer Aided Learning.

Carnevale, D. (2003). The Virtual Lab Experiment. The Chronicle of Higher Education, 49(21).

Cavanaugh, C., Gillan, K. J., Kromrey, J., Hess, M., \& Blomeyer, R. (2004). The Effects of Distance Education On K-12 Student Outcomes: A Meta-Analysis. London: Learning Point Associates.

Chandrasegaran, A. L., Treagust, D. F., \& Mocerino, M. (2007). The Development of a Two-Tier Multiple-Choice Diagnostic Instrument for Evaluating Secondary School Students' Ability to Describe and Explain Chemical Reactions Using Multiple Levels of Representation. Chemistry Education Research and Practice, 8(3), $293-307$. https:/ / doi.org/10.1039/B7RP90006F

Cheung, D. (2008). Facilitating Chemistry Teachers to Implement Inquiry-Based Laboratory Work. International Journal of Science and Mathematics Education, 6(1), 107-130. https:/ / doi.org/10.1007/s10763-007-9102-y

Chiappetta, E. L., \& Adams, A. D. (2004). Inquiry-based Instruction. The Science Teacher, 71(2), 46-50.

Colburn, A. (2000). An Inquiry Primer. Science Scope, 23(6), 42-44.

Coppola, B. P., \& Lawton, R. G. (1995). Who Has the Same Substance That I Have? A Blueprint for Collaborative Learning Activities. Journal of Chemical Education, 72, 1120-1122. https:/ / doi.org/10.1021/ed072p1120

Crowther, D.T. (1999). Here We Grow Again: Applications of Research and Model Inquiry Lessons. Electronic Journal of Science Education, 3(3), 1-4.

Dalgarno, B. (2015). A VRML Virtual Chemistry Laboratory Incorporating Reusable Prototypes for Object $\begin{array}{llll}\text { Manipulation. } & \text { Retrieved } & \text { on } & 10.01 .2017\end{array}$ from http:/ / citeseerx.ist.psu.edu/viewdoc/download?doi=10.1.1.125.3691\&rep=rep1\&type=pdf

Dalgarno, B., Bishop, A. G., \& Bedgood, J. D. R. (2003). The Potential of VL for Distance Education Science Teaching: Reflections from the Development and Evaluation of a Virtual Chemistry Laboratory. Paper Presented at the Uniserve Science Improving Learning Outcomes Symposium, Sydney.

Diker, M. (2011). Virtual Laboratory for Computer Programming Lesson (Master Dissertation), University of Afyon Kocatepe.

Fraenkel, J. R., Wallen, N. E., \& Hyun, H. H. (2012). How to Design and Evaluate Research in Education (8th ed.). New York: McGram-Hill Companies

Franklin, B., Xiang, L., Collett, J., Rhoads, M., \& Osborn, J. (2015). Open Inquiry-Based Learning Elicits Deeper Understanding of Complex Physiological Concepts Compared to Traditional Lecture-Style or GuidedInquiry Learning Methods. The FASEB Journal, 29(1), 541-22.

Georgiou, J., Dimitropoulos, K., \& Manitsaris, A. (2007). A Virtual Reality Laboratory for Distance Education in Chemistry. International Journal of Social Sciences, 2(1), 34-41.

Gershenson, C., Gonzalez, P. P., \& Negrete, J. (2000). Thinking Adaptive: Towards a Behaviours Virtual Laboratory. Paper Presented at the 6. International Conference on the Simulation of Adaptive, Paris.

Green, S. B., \& Salkind, N. J. (2005). Using SPSS for Windows and Macintosh: Analyzing and Understanding Data. New Jersey: Prentice Hall Press.

Hawkins, I., \& Phelps, A. J. (2013). Virtual laboratory vs. traditional laboratory: which is more effective for teaching electrochemistry? Chemistry Education Research and Practice, 14(4), 516-523. https://doi.org/10.1039/C3RP00070B

Hemraj-Benny, T., \& Beckford, I. (2014). Cooperative and inquiry-based learning utilizing art-related topics: Teaching chemistry to community college nonscience majors. Journal of Chemical Education, 91(10), 1618-1622. https://doi.org/10.1021/ed400533r 
Hinrichsen, J., \& Jarrett, D. (1999). Science Inquiry for the Classroom a Literature Review. Oregon: Northwest Regional Educational Laboratory.

Hofstein, A., \& Lunetta, V. N. (1982). The Role of the Laboratory in Science Teaching: Neglected Aspects of Research. Review of educational research, 52(2), 201-217. https:// doi.org/10.3102/00346543052002201

Hofstein, A., \& Lunetta, V. N. (2004). The Laboratory in Science Education: Foundations for the Twenty-First Century. Science education, 88(1), 28-54. https:/ / doi.org/10.1002/sce.10106

Hofstein, A., \& Mamlok-Naaman, R. (2007). The Laboratory in Science Education: The State of the Art. Chemistry Education Research and Practice, 8(2), 105-107. https:/ / doi.org/10.1039/B7RP90003A

Hofstein, A., Shore, R., \& Kipnis, M. (2004). Providing High School Chemistry Students with Opportunities to Develop Learning Skills in an Inquiry-Type Laboratory: A Case Study. International Journal of Science Education, 26(1), 47- 62. https:/ / doi.org/10.1080/0950069032000070342

Hsiao, H. S., Chen, J. C., Hong, J. C., Chen, P. H., Lu, C. C., \& Chen, S. Y. (2017). A five-stage prediction-observationexplanation inquiry-based learning model to improve students' learning performance in science courses. Eurasia Journal of Mathematics Science and Technology Education, 13(7), 3393-3416. https:/ / doi.org/10.12973/eurasia.2017.00735a

Jezierska, K., Podraza, W., Domek, H., \& Szwed, J. (2016). The Virtual Laboratory for Student Understanding of Biophysics. National Academy Science Letters, 39(4), 295-299. https:/ / doi.org/10.1007/s40009-016-0486-5

Johnstone, A. H., \& Wham, A. J. B. (1982). The Demands of Practical Work. Education in Chemistry, 71-73.

Kamlaskar, C. H. (2007). Development and Evaluation of an Interactive Multimedia Simulation on Electronics Lab Activity: Wien Bridge Oscillator. International Journal of Instructional Technology and Distance Learning, 4(3), 13-30.

Karamustafaoglu, O., \& Yaman, S. (2010). Fen Egitiminde Ozel Ogretim Yontemleri I-II. Ankara: Ani Yayincilik.

Kaya, G., \& Yılmaz, S. (2016). Açık sorgulamaya dayalı öğrenmenin öğrencilerin başarısına ve bilimsel süreç becerilerinin gelişimine etkisi [The Impact of Open Inquiry Based Learning on Students' Achievement and Development of Science Process Skills]. Hacettepe Üniversitesi Eğitim Fakültesi Dergisi, 31(2), 300-318. https:// doi.org/10.16986/HUJE.2016016811

Kennepohl, D. (2001). Using Computer Simulations to Supplement Teaching Laboratory in Chemistry for Distance Delivery. The Journal of Distance Education, 16(2), 58-65.

Lily, Q., Gang, Z., Yong, P., Tingfu, M., \& Ming, G. (2008). Three-dimensional Virtual Chemical Laboratory Based on Virtual Reality Modelling Language. Paper Presented at the IEEE International Symposium on IT in Medicine and Education, Xiamen.

Lim, B. R. (2001). Guidelines for Designing Inquiry-Based Learning on the Web: Online Professional Development of Educators (PhD Dissertation), Indiana University.

Lunetta, V. N. (1998). The School Science Laboratory: Historical Perspectives and Centres for Contemporary Teaching. In B. J. Fraser and K. G. Tobin (Ed.), International handbook of science education. Dordrecht: Kluwer. https://doi.org/10.1007/978-94-011-4940-2_16

Mercer-Chalmers, J. D., Goodfellow, C. L., \& Price, G. J. (2004). Using a VLE to Enhance a Foundation Chemistry Laboratory Module. CAL-Laborate, 12, 14-18.

National Research Council (NRC). (2000). Inquiry and National Science Educational Standards. Washington, D.C.: National Academy Press.

Ozdener, N. (2005). Using of Analogy in Experimental Teaching Methods. Turkish Online Journal of Educational Technology, 4(4), 4-13.

Ozkan, E. Ç., \& Bümen, N. T. (2014). Fen ve teknoloji dersinde araştırmaya dayalı öğrenmenin öğrencilerin erişilerine, kavram öğrenmelerine, üstbiliş farkındalıklarına ve fen ve teknoloji dersine yönelik tutumlarına etkisi [The Effects of Inquiry Based Learning in Science and Technology Course on Students' Achievements, Concept Learning, Metacognition Awareness and Attitudes towards Science and Technology Course]. Ege Ĕ̈itim Dergisi, 15(1), 251-278. https:/ / doi.org/10.12984/eed.57325

Pallant, J. (2007). SPSS Survival Manual, a Step by Step a Guide to Data Analysis Using SPSS for Windows. England: McGraw-Hill Education.

Ramnarain, U. D. (2014). Teachers' perceptions of inquiry-based learning in urban, suburban, township and rural high schools: The context-specificity of science curriculum implementation in South Africa. Teaching and teacher education, 38, 65-75. https:/ / doi.org/10.1016/j.tate.2013.11.003

Roth, W. M. (1994). Experimenting in a constructivist high school physics laboratory. Journal of Research in Science Teaching, 31, 197-223. https:// doi.org/10.1002/tea.3660310209 
Schwab, J. J. (1962). The Teaching of Science as Inquiry. In J. J. Schwab and P. F. Brandwein (Ed.), The teaching of science. Cambridge: Harvard University Pres.

Singer, S. R., Hilton, M. L., \& Schweingruber, H. A. (2006). America's Lab Report: Investigations in High School Science. Committee on High School Science Laboratories: Role and Vision. Washington D.C.: National Research Council, National Academies Press.

Stieff, M., \& Wilensky, U. (2003). Connected Chemistry-Incorporating Interactive Simulations into the Chemistry Classroom. Journal of Science Education and Technology, 12(3), 285-302. https:/ / doi.org/10.1023/A:1025085023936

Tatli, Z. (2011). Development, Application and Evaluation of Virtual Chemistry Laboratory Experiments for Chemical Changes Unit at Secondary School 9 $9^{\text {th }}$ Grade Curriculum (PhD Dissertation), Karadeniz Technical University.

Tobin, K. G. (1990). Research on Science Laboratory Activities. In Pursuit of Better Questions and Answers to Improve Learning. School Science and Mathematics, 90, 403-418. https://doi.org/10.1111/j.19498594.1990.tb17229.x

Treagust, D. F. (1988). Development and Use of Diagnostic Tests to Evaluate Students' Misconceptions in Science. International Journal of Science Education, 10(2), 159-169. https:/ / doi.org/10.1080/0950069880100204

Trindade, J., Fiolhais, C., \& Almedia, L. (2002). Science Learning in Virtual Environments: A Descriptive Study. British Journal of Educational Technology, 33(4), 471-488. https:/ / doi.org/10.1111/1467-8535.00283

Tsui, C. Y., \& Treagust, D. (2010). Evaluating Secondary Students' Scientific Reasoning in Genetics Using a TwoTier Diagnostic Instrument. International Journal of Science Education, 32(8), 1073-1098. https:/ / doi.org/10.1080/09500690902951429

Tuysuz, C. (2010). The Effect of the Virtual Laboratory on Students' Achievement and Attitude in Chemistry. International Online Journal of Educational Sciences, 2(1), 37-53.

Wimmers, L. E. (2001). Practicing Real Science in the Laboratory. Journal of College Science Teaching, 31(3), 167-171.

Woodfield, B. (2005). Virtual Chemlab Getting Started, Pearson Education. Retrieved on 26.04.2015 from http:/ / www.mypearsontraining.com/pdfs/VCL_getting_started.pdf

Yang, K. Y., \& Heh J. S. (2007). The Impact of Internet Virtual Physics Laboratory Instruction on the Achievement in Physics, Science Process Skills and Computer Attitudes of 10th Grade Students. Journal of Science Education and Technology, 16, 451-461. https:/ / doi.org/10.1007/s10956-007-9062-6

Yetişir, M. I. (2016). Rehberli Araştırma-Sorgulamaya Dayalı Fizik Öğretimi: Öğretmen Adaylarının Akademik Başarıları Ve Uygulama Hakkındaki Görüşlerinin İncelenmesi [Physics Teaching based on Guided-InquiryBased Learning: Investigation of Pre-service Teachers' Achievement and Opinion about Treatment]. Ankara Üniversitesi Ĕ̆itim Bilimleri Fakültesi Dergisi, 49(1), 159-182. https:/ / doi.org/10.1501/Egifak_0000001379 


\section{APPENDIX}

Alternative conceptions were determined in this research.

\begin{tabular}{|c|c|c|c|c|c|c|c|c|c|c|}
\hline & & & $\bar{A}$ & & & IL & & & & $\overline{R L}$ \\
\hline & & Alternative conception & $\begin{array}{l}\text { Pre Test } \\
\text { (f) }\end{array}$ & $\begin{array}{l}\text { Post Test } \\
\text { (f) }\end{array}$ & $\begin{array}{l}\text { Pre Test } \\
\text { (f) }\end{array}$ & $\begin{array}{l}\text { Post Test } \\
\text { (f) }\end{array}$ & $\begin{array}{l}\text { Pre Test } \\
\text { (f) }\end{array}$ & $\begin{array}{l}\text { Post Test } \\
\text { (f) }\end{array}$ & $\begin{array}{l}\text { Pre Test } \\
\text { (f) }\end{array}$ & $\begin{array}{l}\text { Post Test } \\
\text { (f) }\end{array}$ \\
\hline & 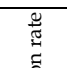 & $\begin{array}{l}\text { Reaction rate is the process of conversion from reactants } \\
\text { to products }\end{array}$ & 10 & 9 & 6 & 4 & 4 & 5 & 2 & 2 \\
\hline & 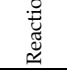 & $\begin{array}{l}\text { The reaction rate indicates how much time a reaction } \\
\text { takes to complete. }\end{array}$ & 2 & 3 & 5 & 6 & 4 & 6 & 5 & 6 \\
\hline & & $\begin{array}{l}\text { When the concentration of reactants decreases, reaction } \\
\text { rate increases. }\end{array}$ & 8 & 5 & 5 & 3 & 3 & 5 & 1 & 6 \\
\hline & 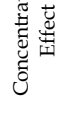 & $\begin{array}{l}\text { As concentration increases, the number of particles per } \\
\text { unit volume also increases; as a result, the particles' } \\
\text { motion area decreases and their collision becomes } \\
\text { difficult. }\end{array}$ & 7 & 7 & 4 & 4 & 8 & 7 & 9 & 2 \\
\hline & 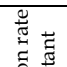 & $\begin{array}{l}\text { Reaction rate constant depends on the concentration of } \\
\text { reactants. }\end{array}$ & 4 & 5 & 7 & 7 & 7 & 4 & 10 & 7 \\
\hline & 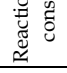 & $\begin{array}{l}\text { When concentration increases, effective collision increases } \\
\text { and thus reaction rate constant increases. }\end{array}$ & 4 & 5 & 7 & 6 & 7 & 4 & 10 & 8 \\
\hline & 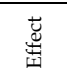 & $\begin{array}{l}\text { When surface area increases, the reaction rate decreases } \\
\text { for equal amounts of the same substances. }\end{array}$ & 9 & 8 & 11 & 7 & 10 & 8 & 14 & 6 \\
\hline & 莺 & $\begin{array}{l}\text { When surface area increases, the molecules' kinetic energy } \\
\text { decreases for equal amounts of the same substances } \\
\text { because the volume of reaction environment decreases. }\end{array}$ & 5 & 6 & 4 & 3 & 4 & 2 & 5 & 4 \\
\hline U్ & & Catalysts do not affect reaction. & 11 & 11 & 9 & 6 & 13 & 12 & 11 & 8 \\
\hline 鳬 & 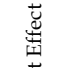 & $\begin{array}{l}\text { Catalysts do not affect reaction rate because they do not } \\
\text { run out in the reaction. }\end{array}$ & 10 & 9 & 9 & 7 & 7 & 9 & 11 & 7 \\
\hline 岁 & 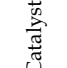 & $\begin{array}{l}\text { Catalysts make possible the reaction to reach the } \\
\text { equivalence point, fast. }\end{array}$ & 2 & 2 & 4 & 5 & 6 & 5 & 5 & 1 \\
\hline 島 & & Catalysts provide more yielding reactions. & 9 & 8 & 4 & 3 & 6 & 5 & 5 & 11 \\
\hline & 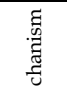 & $\begin{array}{l}\text { The reaction rate constant of the fast step is greater than } \\
\text { the slow step's reaction rate constant in a reaction that has } \\
\text { two-steps }\end{array}$ & 10 & 9 & 10 & 8 & 13 & 13 & 13 & 9 \\
\hline & 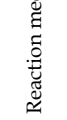 & $\begin{array}{l}\text { The reaction rate constant of the slow step is greater than } \\
\text { the fast step's reaction rate constant in a reaction which } \\
\text { has two-steps because the reaction rate depends on the } \\
\text { slow step. }\end{array}$ & 8 & 10 & 7 & 6 & 11 & 10 & 14 & 8 \\
\hline & $\vec{u}$ & $\begin{array}{l}\text { When the temperature increases, the reaction rate } \\
\text { increases in endothermic reactions and the reaction rate } \\
\text { decreases in exothermic reactions. }\end{array}$ & 12 & 14 & 9 & 10 & 14 & 12 & 15 & 8 \\
\hline & 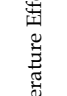 & $\begin{array}{l}\text { The effect of temperature on reaction rate is in an } \\
\text { enhancer direction in endothermic reactions and in a } \\
\text { detractive direction in exothermic reactions. }\end{array}$ & 10 & 13 & 10 & 13 & 15 & 14 & 13 & 9 \\
\hline & 气े & $\begin{array}{l}\text { When the temperature increases, the reaction rate } \\
\text { increases very much in the endothermic reaction but it } \\
\text { increases at first but later decreases in the exothermic } \\
\text { reaction. }\end{array}$ & 8 & 10 & 6 & 6 & 9 & 10 & 9 & 6 \\
\hline & 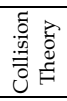 & $\begin{array}{l}\text { Each atom in a molecule should come into a collision with } \\
\text { any other atom in the other molecule for an effective } \\
\text { collision. }\end{array}$ & 7 & 5 & 9 & 9 & 11 & 11 & 7 & 8 \\
\hline & $\frac{0}{2}$ & $\begin{array}{l}\text { If an intervention is made to a reaction that is at } \\
\text { equilibrium at a constant temperature, the equilibrium is } \\
\text { re-established by the concentration of the products and } \\
\text { the reactants which are equalled. }\end{array}$ & 7 & 8 & 4 & 3 & 6 & 7 & 4 & 4 \\
\hline 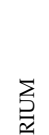 & 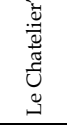 & $\begin{array}{l}\text { If an intervention is made to a reaction that is at } \\
\text { equilibrium at a constant temperature, the equilibrium is } \\
\text { re-established because some substances run out in the } \\
\text { reaction. }\end{array}$ & 5 & 2 & 5 & 3 & 4 & 3 & 1 & 8 \\
\hline 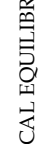 & 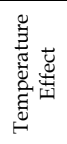 & $\begin{array}{l}\text { If the temperature increases, the reaction always favours } \\
\text { the product in exothermic equilibrium reactions. }\end{array}$ & 7 & 3 & 7 & 1 & 4 & 0 & 4 & 3 \\
\hline$\sum_{|=|}^{\mid}$ & 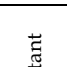 & $\begin{array}{l}\text { When the temperature increases, the equilibrium constant } \\
\text { decreases in endothermic reactions. }\end{array}$ & 4 & 1 & 6 & 6 & 4 & 4 & 4 & 3 \\
\hline & $\underbrace{\vec{t}}_{0}$ & $\begin{array}{l}\text { When the temperature increases, the equilibrium constant } \\
\text { is not affected. }\end{array}$ & 8 & 4 & 6 & 7 & 8 & 6 & 5 & 8 \\
\hline & 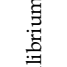 & $\begin{array}{l}\text { When the temperature increases, the equilibrium constant } \\
\text { increases only in endothermic reactions }\end{array}$ & 8 & 2 & 8 & 1 & 7 & 2 & 3 & 5 \\
\hline & 苛 & $\begin{array}{l}\text { When the temperature increases, the equilibrium constant } \\
\text { decreases only in exothermic reactions }\end{array}$ & 2 & 5 & 3 & 4 & 5 & 4 & 8 & 0 \\
\hline
\end{tabular}


Mutlu \& Acar-Şeşen / Pre-service Science Teachers' Understanding

\begin{tabular}{|c|c|c|c|c|c|c|c|c|c|c|}
\hline & & \multirow[b]{2}{*}{ Alternative conception } & \multicolumn{2}{|c|}{ AIL } & \multicolumn{2}{|c|}{ VIL } & \multicolumn{2}{|c|}{ VRL } & \multicolumn{2}{|c|}{ ARL } \\
\hline & & & $\begin{array}{l}\text { Pre Test } \\
\text { (f) }\end{array}$ & $\begin{array}{l}\text { Post Test } \\
\text { (f) }\end{array}$ & $\begin{array}{l}\text { Pre Test } \\
\text { (f) }\end{array}$ & $\begin{array}{l}\text { Post Test } \\
\text { (f) }\end{array}$ & $\begin{array}{l}\text { Pre Test } \\
\text { (f) }\end{array}$ & $\begin{array}{l}\text { Post Test } \\
\text { (f) }\end{array}$ & $\begin{array}{l}\text { Pre Test } \\
\text { (f) }\end{array}$ & $\begin{array}{l}\text { Post Test } \\
\text { (f) }\end{array}$ \\
\hline \multirow{9}{*}{ 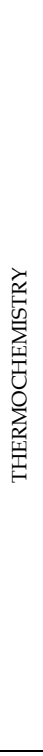 } & \multirow{2}{*}{ 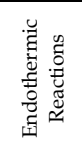 } & $\begin{array}{l}\text { The activation energy for the reverse reaction is greater than } \\
\text { the activation energy for the forward reaction in } \\
\text { endothermic equilibrium reactions. }\end{array}$ & 8 & 9 & 8 & 3 & 5 & 6 & 8 & 7 \\
\hline & & $\begin{array}{l}\text { An endothermic equilibrium reaction reaches activation } \\
\text { energy faster because it gets energy from outside. }\end{array}$ & 4 & 3 & 5 & 3 & 4 & 3 & 4 & 3 \\
\hline & \multirow{3}{*}{ 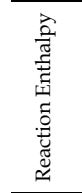 } & $\begin{array}{l}\text { Reaction enthalpy is the temperature difference between the } \\
\text { system and the environment. }\end{array}$ & 7 & 4 & 5 & 3 & 6 & 3 & 6 & 6 \\
\hline & & $\begin{array}{l}\text { Reaction enthalpy is the temperature difference between } \\
\text { before and after the reaction. }\end{array}$ & 7 & 4 & 8 & 5 & 3 & 5 & 8 & 1 \\
\hline & & $\begin{array}{l}\text { Reaction enthalpy is the temperature difference stored in the } \\
\text { products' and reactants' chemical bonds. }\end{array}$ & 6 & 5 & 7 & 3 & 10 & 7 & 6 & 10 \\
\hline & \multirow{2}{*}{ 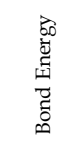 } & $\begin{array}{l}\text { The energy required to break the bonds in the reactants' } \\
\text { molecules is greater than the energy required for the } \\
\text { formation of bonds in the products' molecules in exothermic } \\
\text { reactions. }\end{array}$ & 5 & 7 & 7 & 7 & 3 & 10 & 8 & 9 \\
\hline & & The energy stored in chemical bonds is released by reactions. & 3 & 2 & 5 & 2 & 6 & 2 & 8 & 0 \\
\hline & 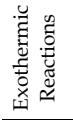 & $\begin{array}{l}\text { The energy stored in products' bonds is less than the energy } \\
\text { stored in reactants' bonds in exothermic reactions. }\end{array}$ & 2 & 6 & 4 & 9 & 5 & 8 & 3 & 5 \\
\hline & 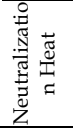 & $\begin{array}{l}\text { A reaction that occurs between an acid solution and a base } \\
\text { solution has greater heat of neutralization than a reaction } \\
\text { that occurs between a solid base and an acid solution. }\end{array}$ & 7 & 3 & 4 & 4 & 6 & 2 & 6 & 5 \\
\hline \multirow{25}{*}{ 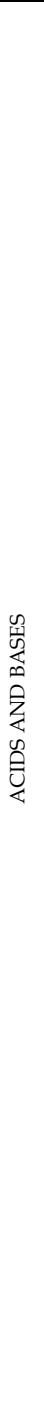 } & \multirow{8}{*}{ 兽 } & $\begin{array}{l}\mathrm{pH} \text { is } 7 \text { at the equivalence point in the titration of strong base } \\
\text { and weak acid }\end{array}$ & 7 & 6 & 9 & 5 & 6 & 4 & 7 & 6 \\
\hline & & Weak bases cannot be titrated with weak acids. & 6 & 8 & 6 & 7 & 8 & 10 & 5 & 7 \\
\hline & & $\begin{array}{l}\mathrm{pH} \text { is always } 7 \text { at the equivalence point in a titration in } \\
\text { which a strong base is a titrant and a weak acid is an analyte. }\end{array}$ & 6 & 5 & 7 & 5 & 6 & 3 & 5 & 9 \\
\hline & & $\begin{array}{l}\mathrm{pH} \text { is always between } 3 \text { and } 7 \text { at the equivalence point in a } \\
\text { titration in which a strong base is a titrant and a weak acid is } \\
\text { an analyte. }\end{array}$ & 5 & 5 & 5 & 4 & 5 & 8 & 9 & 8 \\
\hline & & Weak acids/weak bases cannot be titrated. & 4 & 2 & 6 & 3 & 9 & 4 & 8 & 7 \\
\hline & & $\begin{array}{l}\text { Any indicator changes colour at the turning point in a } \\
\text { titration. }\end{array}$ & 4 & 2 & 4 & 2 & 8 & 3 & 7 & 2 \\
\hline & & $\begin{array}{l}\text { Titration depends on only the neutralization of acid and } \\
\text { base, the indicator is not important in the titration. }\end{array}$ & 8 & 0 & 4 & 0 & 3 & 0 & 3 & 1 \\
\hline & & Acid and base must be at an equal volume for titration. & 3 & 1 & 5 & 2 & 5 & 0 & 5 & 2 \\
\hline & \multirow{6}{*}{ 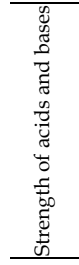 } & $\mathrm{pH}$ is the measure of acidity strength. & 11 & 4 & 15 & 6 & 14 & 6 & 14 & 5 \\
\hline & & The strength of acids is determined by a pH meter. & 8 & 7 & 14 & 7 & 9 & 7 & 8 & 8 \\
\hline & & $\begin{array}{l}\text { The strength of acids is determined by the concentration of } \\
\text { solution. }\end{array}$ & 4 & 3 & 0 & 0 & 2 & 0 & 5 & 2 \\
\hline & & If $\mathrm{pH}$ decreases, the strength of acids will increase. & 8 & 5 & 12 & 5 & 7 & 7 & 7 & 9 \\
\hline & & $\mathrm{pH}$ of strong bases is close to 14 . & 8 & 1 & 6 & 2 & 11 & 6 & 8 & 7 \\
\hline & & If $\mathrm{pH}$ is close to 1 , the strength of acids increases. & 12 & 7 & 12 & 4 & 12 & 6 & 11 & 6 \\
\hline & \multirow{3}{*}{ 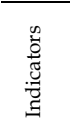 } & Indicators increase the reaction rate. & 2 & 2 & 6 & 6 & 5 & 3 & 9 & 6 \\
\hline & & Indicators decrease the reaction rate. & 11 & 1 & 10 & 0 & 11 & 3 & 6 & 2 \\
\hline & & $\begin{array}{l}\text { Indicators provide an alternative way for the reaction to } \\
\text { happen that has a lower activation energy. }\end{array}$ & 6 & 3 & 9 & 3 & 7 & 1 & 11 & 3 \\
\hline & \multirow{8}{*}{ 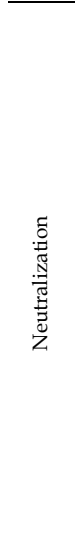 } & $\begin{array}{l}\text { If an acid solution and a base solution are mixed in any } \\
\text { amount, the } \mathrm{pH} \text { is always } 7 \text {. }\end{array}$ & 6 & 3 & 6 & 6 & 5 & 7 & 7 & 12 \\
\hline & & $\begin{array}{l}\text { Neutralization reaction does not occur between weak acids } \\
\text { and weak bases. }\end{array}$ & 4 & 5 & 4 & 2 & 3 & 8 & 8 & 5 \\
\hline & & $\begin{array}{l}\text { If an acid solution at equal volume and concentration is } \\
\text { added to a base solution, salt and water are always formed. }\end{array}$ & 7 & 4 & 11 & 5 & 9 & 8 & 11 & 6 \\
\hline & & If an equal amount of acid and base react, $\mathrm{pH}$ is always 7. & 10 & 1 & 5 & 6 & 4 & 3 & 1 & 4 \\
\hline & & $\begin{array}{l}\text { If an acid solution at equal volume and concentration is } \\
\text { added to a base solution, acid gives its } \mathrm{H}^{+} \text {to base's } \mathrm{OH}^{-} \text {and } \\
\text { water is formed. }\end{array}$ & 6 & 5 & 4 & 3 & 7 & 7 & 11 & 8 \\
\hline & & $\begin{array}{l}\text { Neutralization occurs between only a strong acid and a } \\
\text { strong base. }\end{array}$ & 1 & 1 & 4 & 0 & 4 & 1 & 4 & 2 \\
\hline & & $\begin{array}{l}\text { If a base solution at any amount is added to an acid solution, } \\
\text { the concentration of } \mathrm{H}_{3} \mathrm{O}^{+} \text {is greater than the concentration of } \\
\mathrm{OH}^{-} \text {in that solution. }\end{array}$ & 6 & 13 & 3 & 0 & 5 & 11 & 4 & 8 \\
\hline & & $\begin{array}{l}\text { If a base solution of any amount is added to an acid solution, } \\
\text { the concentration of } \mathrm{H}_{3} \mathrm{O}^{+} \text {is equal to the concentration of } \\
\mathrm{OH}^{-} \text {in solution. }\end{array}$ & 5 & 1 & 4 & 3 & 2 & 5 & 0 & 2 \\
\hline
\end{tabular}


EURASIA J Math Sci and Tech Ed

\begin{tabular}{|c|c|c|c|c|c|c|c|c|c|c|}
\hline & & \multirow[b]{2}{*}{ Alternative conception } & \multicolumn{2}{|c|}{ AIL } & \multicolumn{2}{|c|}{ VIL } & \multicolumn{2}{|c|}{ VRL } & \multicolumn{2}{|c|}{ ARL } \\
\hline & & & $\begin{array}{l}\text { Pre Test } \\
\text { (f) }\end{array}$ & $\begin{array}{l}\text { Post Test } \\
\text { (f) }\end{array}$ & $\begin{array}{l}\text { Pre Test } \\
\text { (f) }\end{array}$ & $\begin{array}{l}\text { Post Test } \\
\text { (f) }\end{array}$ & $\begin{array}{l}\text { Pre Test } \\
\text { (f) }\end{array}$ & $\begin{array}{l}\text { Post Test } \\
\text { (f) }\end{array}$ & $\begin{array}{l}\text { Pre Test } \\
\text { (f) }\end{array}$ & $\begin{array}{l}\text { Post Test } \\
\text { (f) }\end{array}$ \\
\hline \multirow{12}{*}{ 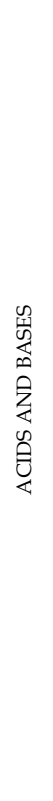 } & $\vec{\Xi}$ & $\mathrm{pH}$ is always 7 at the equivalence point. & 11 & 2 & 14 & 7 & 13 & 1 & 14 & 6 \\
\hline & ֻ̆ & Solutions are always neutral at the equivalence point. & 10 & 2 & 11 & 7 & 8 & 1 & 10 & 5 \\
\hline & 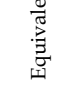 & $\begin{array}{l}\mathrm{pH} \text { is always } 7 \text { at the equivalence point because } \\
\text { neutralization occurs fully. }\end{array}$ & 6 & 6 & 8 & 5 & 6 & 3 & 4 & 3 \\
\hline & 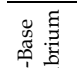 & $\begin{array}{l}\text { If a base is added to an acid solution at equilibrium, the } \\
\text { reaction favours the products. }\end{array}$ & 6 & 7 & 5 & 4 & 8 & 6 & 13 & 7 \\
\hline & 喥 & $\begin{array}{l}\text { If a base is added to an acid solution at equilibrium, the } \\
\text { reaction equilibrium does not change. }\end{array}$ & 4 & 5 & 7 & 6 & 1 & 6 & 1 & 8 \\
\hline & \multirow{7}{*}{ 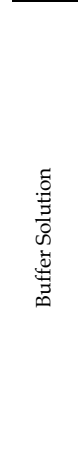 } & If acid/base is added to buffer, the solution's pH is fixed at 7. & 7 & 2 & 6 & 3 & 9 & 0 & 10 & 3 \\
\hline & & $\begin{array}{l}\text { Acid and its conjugate base should neutralize each other in } \\
\text { buffers. }\end{array}$ & 9 & 8 & 5 & 10 & 11 & 10 & 10 & 11 \\
\hline & & $\begin{array}{l}\text { If the acid component of the buffer is not strong, the buffer } \\
\text { does not resist pH change. }\end{array}$ & 4 & 3 & 5 & 1 & 3 & 1 & 1 & 1 \\
\hline & & $\begin{array}{l}\text { If a little amount of strong base is added to a buffer, the } \\
\text { strong base and base component of buffer combine and } \mathrm{pH} \\
\text { gets closer to } 14 \text {. }\end{array}$ & 13 & 1 & 8 & 2 & 12 & 6 & 9 & 8 \\
\hline & & $\begin{array}{l}\text { If a little amount of strong base is added to buffer, the base } \\
\text { component of the buffer becomes a proton receiver. }\end{array}$ & 4 & 2 & 4 & 7 & 3 & 5 & 6 & 3 \\
\hline & & $\begin{array}{l}\text { If a little amount of strong base is added to buffer, the base } \\
\text { component of buffer takes a proton from the acid component } \\
\text { of the buffer and it fixes [conjugate base]/ [conjugate acid] }\end{array}$ & 3 & 4 & 5 & 9 & 4 & 4 & 8 & 6 \\
\hline & & $\begin{array}{l}\text { If acid/base is added to a buffer, the } \mathrm{pH} \text { remains fixed at } 7 \\
\text { because buffers neutralize acids and bases. }\end{array}$ & 9 & 2 & 7 & 4 & 9 & 1 & 11 & 6 \\
\hline \multirow{12}{*}{ 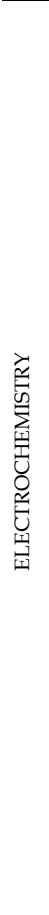 } & 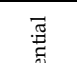 & $\begin{array}{l}\text { The potential of an electrochemical cell is independent of the } \\
\text { concentration of electrolyte in the half-cells. }\end{array}$ & 8 & 1 & 9 & 2 & 6 & 2 & 8 & 3 \\
\hline & $\begin{array}{l}\stackrel{\overline{0}}{\Xi} \\
\overline{\bar{\Xi}}\end{array}$ & $\begin{array}{l}\text { When electrolyte concentration increases, ion concentration } \\
\text { and electron movement increase. Therefore, cell potential } \\
\text { increases. }\end{array}$ & 5 & 6 & 6 & 10 & 8 & 8 & 4 & 10 \\
\hline & $\stackrel{\mathscr{e}}{g}$ & High reactive metals reduce, low reactive metals oxidize. & 10 & 9 & 10 & 9 & 11 & 7 & 12 & 7 \\
\hline & 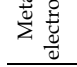 & $\begin{array}{l}\text { If metals' activity is high, their reduction potential is high } \\
\text { but their oxidation potential is low. }\end{array}$ & 2 & 5 & 6 & 5 & 7 & 4 & 11 & 4 \\
\hline & \multirow{6}{*}{ 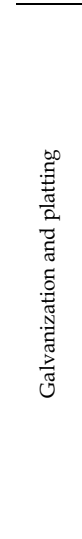 } & Galvanization depends on the principle of electrolysis. & 3 & 4 & 5 & 3 & 4 & 8 & 9 & 4 \\
\hline & & $\begin{array}{l}\text { In galvanization of iron with zinc, it must be energized for } \\
\text { reduction of the iron electrode at the anode and oxidation of } \\
\text { the zinc electrode at the cathode. }\end{array}$ & 8 & 3 & 5 & 2 & 7 & 0 & 6 & 10 \\
\hline & & $\begin{array}{l}\text { In galvanization of iron with zinc, during the process of } \\
\text { reducing the iron electrode at the cathode and oxidizing the } \\
\text { zinc electrode at the anode, energy is released. }\end{array}$ & 5 & 6 & 6 & 9 & 6 & 4 & 1 & 2 \\
\hline & & $\begin{array}{l}\text { In the process of covering a copper plate with tin, whose } \\
\text { oxidation potential is greater than copper, tin is the positive } \\
\text { and copper is the negative pole. }\end{array}$ & 11 & 4 & 12 & 4 & 9 & 3 & 7 & 9 \\
\hline & & $\begin{array}{l}\text { In the process of covering a copper plate with tin, whose } \\
\text { oxidation potential is greater than copper, electrons which } \\
\text { occur after the oxidation of tin at the anode go to copper at } \\
\text { the cathode and they lead copper to be reduced. }\end{array}$ & 6 & 9 & 8 & 12 & 6 & 11 & 10 & 7 \\
\hline & & $\begin{array}{l}\text { In the process of covering a copper plate with tin, whose } \\
\text { oxidation potential is greater than copper, electrons that } \\
\text { occur after the oxidation of tin at the cathode go to copper at } \\
\text { the anode and they lead copper to be reduced. }\end{array}$ & 4 & 2 & 8 & 12 & 5 & 1 & 3 & 4 \\
\hline & \multirow{2}{*}{ 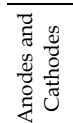 } & $\begin{array}{l}\text { When the number of electrodes increases, reduction } \\
\text { potential increases. }\end{array}$ & 4 & 0 & 5 & 0 & 3 & 1 & 6 & 2 \\
\hline & & $\begin{array}{l}\text { The anode is positively charged and the cathode is } \\
\text { negatively charged in an electrochemical cell. }\end{array}$ & 4 & 0 & 4 & 1 & 2 & 0 & 2 & 0 \\
\hline
\end{tabular}

\section{http://www.ejmste.com}

